\title{
The Relationship Between Restless Legs Syndrome and Anxiety, Depression, and Quality of Life
}

\author{
- Şenay Aydın, ${ }^{1}$ (1) Cengiz Özdemir²
}

\begin{tabular}{r} 
'Department of Neurology, Yedikule \\
Chest Diseases and Chest Surgery \\
Training and Research Hospital, \\
İstanbul, Turkey \\
2Department of Chest Diseases, \\
Yedikule Chest Diseases and Chest \\
Surgery Training and Research \\
Hospital, İstanbul, Turkey \\
Submitted: 16.04 .2019 \\
Accepted: 21.05 .2019 \\
\hline Correspondence: Şenay Aydın, \\
Yedikule Göğüs Hastalıkları ve \\
Göğüs Cerrahisi Eğitim ve Araştırma \\
Hastanesi, Nöroloji Kliniği, \\
34020 Zeytinburnu, İstanbul, Turkey \\
E-mail: aydin.senay@hotmail.com
\end{tabular}

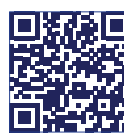

Keywords: Anxiety; depression; quality of life; restless legs syndrome.

This work is licensed under a Creative Commons Attribution-NonCommercial 4.0 International License.

\begin{abstract}
Objective: Restless legs syndrome (RLS) is a common sleep disorder. In addition to disturbing sleep, however, RLS also affects quality of life and may lead to significant fatigue or psychiatric symptoms. This study was an examination of the effects of RLS on quality of life and symptoms of anxiety and depression.
\end{abstract}

Methods: In this study, 55 patients (7 males and 48 females) who met the diagnostic criteria of idiopathic RLS and 35 healthy individuals ( 8 males, 27 females) were evaluated using validated Turkish versions of the Pittsburgh Sleep Quality Index (PSQI), the Epworth Sleepiness Scale (ESS), Insomnia Severity Index (ISI), the International Restless Legs Syndrome Study Group (IRLSSG) rating scale for the severity of RLS, Beck Depression Inventory (BDI), Beck Anxiety Inventory (BAI), the Fatigue Severity Scale (FSS), and the Short Form Health Survey (SF-36), which measures quality of life.

Results: Fifty-two patients who met the diagnostic criteria for idiopathic RLS were evaluated in Group I and 35 healthy controls were included in Group II. A statistically significant difference was observed in the PSQI, ESS, ISI, BDI, BAI, FSS, and SF-36 questionnaire results in the RLS group compared with the control group. The mean score of the SF-36 Physical Component Summary (PCS) scale was significantly lower among RLS patients than that of the healthy subjects. There was a negative correlation between the PCS score and RLS severity, fatigue, insomnia, daytime sleepiness, sleep quality, anxiety, and the level of depressive symptoms. Multivariate linear regression analysis indicated that the FSS and BDI values were influential variables on the PCS score.

Conclusion: The results of the present study demonstrated that patients with idiopathic RLS experienced significantly impaired quality of life and the psychiatric symptoms of anxiety and depression.

\section{INTRODUCTION}

Restless legs syndrome (RLS) is a common sleep-related movement disorder characterized by 5 key criteria determined by the International Restless Legs Syndrome Study Group (IRLSSG).

Patients feel uneasy, uncomfortable, and have difficulty falling asleep due to an urge to move the extremities, most often the legs, which typically starts in the evening or while at rest, and is characterized by unexplained, painful sensorimotor symptoms, such as sensations of burning, ache, tingling, chills, and freezing. ${ }^{[1-3]}$ The prevalence of RLS observed in the Turkish population has been reported to be between $3.19 \%$ and $22.2 \%$. It is seen twice as frequently in the female gender and the incidence increases with age. ${ }^{[4-6]}$ Chronic sleep deprivation is particularly prominent in RLS patients with daytime symptoms. ${ }^{[7]}$ Psychiatric symptoms that affect the quality of life, such as fatigue, depression, and anxiety, have been observed more frequently in RLS patients compared with healthy individuals. ${ }^{[8-10]}$

The Short Form Health Survey (SF-36), which evaluates quality of life, and the Beck Anxiety Inventory (BAl) and the Beck Depression Inventory (BDI), employed in the diagnosis of anxiety and depression symptoms, are widely used to evaluate the mental and physical health status of patients. There are currently few studies of the impact of RLS on quality of life in the Turkish population.

The aim of this study was to investigate the effects of RLS on the quality of life of patients and the psychiatric variables of anxiety and depression.

\section{MATERIALS AND METHODS}

This study included 55 patients (Group I) who presented 
at a neurology outpatient clinic. These patients met the diagnostic criteria for idiopathic RLS and had no secondary causes, including RDS, other sleep disorders, iron-deficiency anemia, endocrine diseases, renal failure, pregnancy, or breastfeeding. The control group (Group II) consisted of 35 healthy volunteers without any diagnosed psychiatric, chronic, or systemic disease or sleep disorder. ${ }^{[1]}$

Patients who had symptoms of insomnia but who did not meet the RLS diagnostic criteria, those who had been diagnosed with RLS previously and received regular treatment, and individuals who described snoring or reported witnessed apnea due to possible sleep apnea syndrome were excluded from the study. Individuals who had not completed at least 5 years of formal basic education and those who had past or present history of smoking or alcohol use were also excluded. Written, informed consent was obtained from the patients enrolled in the study. Local ethics committee approval (2015/8) was obtained.

The length of formal education, and the anthropometric measurements of body mass index (BMI) and waistto-hip ratio of all of the participants were documented. Laboratory data related to fasting blood glucose, urea, creatinine, uric acid, total cholesterol, triglyceride, highdensity lipoprotein cholesterol, low-density lipoprotein cholesterol, iron, ferritin, triiodothyronine, thyroxine, thyroid-stimulating hormone, vitamin $\mathrm{BI}$, folate, C-reactive protein, sedimentation rate, and hemogram values were recorded.

A neurological examination was performed and sleep disorders were evaluated by a neurologist during face-to-face interviews. Validated Turkish versions of the following scales were used to assess the participants.

The Pittsburgh Sleep Quality Index (PSQI), Epworth Sleepiness Scale (ESS), and the Insomnia Severity Index (ISI) were used to evaluate sleep status; the presence and severity of RLS were determined using the IRLSSG rating scale; the level of existing depression and anxiety was measured with the BDI and the BAl; and the Fatigue Severity Scale (FSS) and the SF-36 were used to assess fatigue and quality of life.

The IRLSSG scale is composed of 10 questions, each of which is graded between 0 and 4 points. Based on the total score, the severity of RLS is considered mild (0-10), moderate (II-20), severe (2I-30), or very severe (3I-40). [II] The PSQI is a 19-item self-report scale that assesses sleep quality and indicates the presence of sleep disorders. A PSQI total score greater than 5 indicates poor sleep. ${ }^{[12]}$

The ESS was developed by Johns et al. to qualitatively and quantitatively measure sleep status and to assess daytime sleepiness. The total score can range from 0 to 24 points, and a score greater than 10 generally indicates excessive daytime sleepiness. ${ }^{[13,14]}$ The ISI is used for the clinical evaluation of insomnia. This Likert- type scale consists of 7 questions with a maximum possible score of 28 points. $[15,16]$ The BAI and BDI are both 21-item Likert-type, self-report evaluations. Items are rated between 0 and 3 points, with a total score that ranges between 0 and 63 points. The score is proportional to the severity of anxiety or depression. ${ }^{[16,17]}$ The FSS is a self-report scale consisting of 9 items, each rated between $I$ and 7 points. The final score (total points/9) is directly proportional to the severity of fatigue. ${ }^{[18]}$

The SF-36 questionnaire consists of components measuring physical functioning (PF), social functioning (SF), role limitation due to physical problems (RP), role limitation due to emotional difficulties (RE), mental health $(M H)$, energy and vitality (VT), bodily pain (BP), and general health perception $(\mathrm{GH})$. Quality of life is measured using scoring algorithms that convert each component into a scale 0 to 100. A lower result indicates greater disability and less quality of life. Physical Component Summary (PCS) and Mental Component Summary (MCS) scores were also calculated using a standard algorithm. ${ }^{[19]}$

The laboratory results and questionnaire data of all of the individuals in Groups I and II were compared and the statistical significance was analyzed.

\section{Statistical analysis}

IBM SPSS Statistics for Windows, Version 22.0 software (IBM Corp., Armonk, NY, USA) was used to perform the statistical analysis. Mean, SD, median, minimum, maximum, frequency, and percentage values were used as descriptive statistics. The distribution of the variables was evaluated using the Kolmogorov-Smirnov test. Student's t-test was used for continuous variables and a chi-square test for categorical variables. Pearson correlation analysis was applied to examine relationships between variables. Multivariate linear regression analysis was employed to determine dependent variables that might affect the SF36 score in patients with RLS. The results were evaluated with a confidence interval of $95 \%$ and a significance level of $\mathrm{p}<0.05$.

\section{RESULTS}

A total of 90 participants who met the inclusion criteria were enrolled in the study. The mean age of the 55 patients in Group I ( 7 male, 48 female) was $40.05 \pm 10.2$ years, and it was $35.89 \pm 9.4$ years for the 35 healthy individuals in Group II (8 male, 27 female) (Table I). In Group I, the mean age of onset of RLS was $32.18 \pm 8.46$ years with a mean duration of RLS of $7.18 \pm 7.36$ years. The most common symptom was sensory complaints $(n=50,90.9 \%)$ and 30 (54.5\%) patients had daytime symptoms. According to the IRLSSG rating scale, the RLS symptoms were mild in $1.8 \%$ of the participants, moderate in $29.1 \%$, severe in $43.6 \%$, and very severe in $25.4 \%$. (Table 2 ).

No statistically significant difference was found in terms of age, gender, length of education, height, weight, waist circumference, hip circumference, or waist-to-hip ratio measurements compared with the control group. However, the mean BMI was significantly greater in patients with RLS $(p=0.005)$ (Table I). No statistically significant difference 
Table I. Comparison of demographic data in the RLS and control groups

\begin{tabular}{|c|c|c|c|c|c|c|c|}
\hline & \multicolumn{3}{|c|}{ RLS group $(n=55)$} & \multicolumn{3}{|c|}{ Control group $(n=35)$} & \multirow[t]{2}{*}{$\mathbf{p}$} \\
\hline & $\mathbf{n}$ & $\%$ & Mean \pm SD & $\bar{n}$ & $\%$ & Mean $\pm S D$ & \\
\hline \multicolumn{8}{|l|}{ Gender } \\
\hline Male & 7 & 12.7 & & 8 & 22.9 & 0.209 & \\
\hline Female & 48 & 87.3 & & 27 & 77.1 & & \\
\hline Age (years) & & & $40.05 \pm 10.25$ & & & $35.89 \pm 9.40$ & 0.056 \\
\hline Education (years) & & & $10.54 \pm 3.78$ & & & $11.65 \pm 3.97$ & 0.186 \\
\hline Height (m) & & & $1.56 \pm 0.68$ & & & $1.60 \pm 0.98$ & 0.064 \\
\hline Weight (kg) & & & $68.25 \pm 12.01$ & & & $63.40 \pm 13.03$ & 0.074 \\
\hline Body mass index $\left(\mathrm{kg} / \mathrm{m}^{2}\right)$ & & & $26.33 \pm 4.35$ & & & $23.64 \pm 4.21$ & $0.005^{*}$ \\
\hline Waist circumference $(\mathrm{cm})$ & & & $85.67 \pm 12.23$ & & & $82.22 \pm 12.73$ & 0.204 \\
\hline Hip circumference $(\mathrm{cm})$ & & & $100.92 \pm 10.52$ & & & $97.62 \pm 7.76$ & 0.092 \\
\hline Waist-hip ratio (\%) & & & $0.85 \pm 0.11$ & & & $0.83 \pm 0.09$ & 0.524 \\
\hline
\end{tabular}

*: Statistically significant at p<0.05.; RLS: Restless legs syndrome; SD: Standard deviation.

Table 2. Clinical data of RLS patients $(n=55)$

\begin{tabular}{lc}
\hline & Mean \pm SD (min-max) \\
\hline Age at onset of RLS (years) & $32.18 \pm 8.46(15-48)$ \\
Duration of RLS (years) & $7.18 \pm 7.36(1-35)$ \\
IRLSSG severity score & $24.04 \pm 7.39(6-37)$ \\
Family history (yes), $\mathrm{n}(\%)$ & $26(47.27)$ \\
Symptoms, $\mathrm{n}$ (\%) & \\
Unexplained sensations & $50(90.9)$ \\
Hypoesthesia & $23(41.8)$ \\
Hyperalgesia & $30(54.5)$ \\
Pain & $24(43.6)$ \\
Cramping & $31(56.3)$ \\
Daytime symptoms & $30(54.5)$ \\
IRLSSG rating, $\mathrm{n}$ (\%) & \\
Mild & $1(1.8)$ \\
Moderate & $16(29.1)$ \\
Severe & $24(43.6)$ \\
Very severe & $14(25.4)$ \\
\hline
\end{tabular}

IRLSSG: International Restless Legs Syndrome Study Group; RLS: Restless legs syndrome; SD: Standard deviation; Min: Minimum; Max: Maximum.

was detected between the groups in the laboratory data. There was a positive correlation between the $\mathrm{BMI}$ and the PSQI $(r=0.340 ; p=0.00 I)$ and $B A I(r=0.248 ; p=0.018)$.

The PSQI, EPS, SCS, ISI, BDI, BAI and FSS results were significantly higher in cases with RLS relative to the control group $(p=0.00 \mathrm{I}, \mathrm{p}=0.00 \mathrm{I}, \mathrm{p}=0.00 \mathrm{I}, \mathrm{p}=0.00 \mathrm{I}, \mathrm{p}=0.00 \mathrm{I}$, and $p=0.00 \mathrm{I}$, respectively) (Table 3 ). In addition, the SF-36 scale scores were significantly lower in the PF, RP, VT, SF, and $\mathrm{MH}$ components, as well as the PCS, in the RLS group compared with the control group $(p=0.044, p=0.008$, $p=0.016, p=0.007, p=0.017$, and $p=0.001$, respectively) (Table 3).

The relationship between possible factors that may affect the PCS was investigated using Pearson correlation
Table 3. Comparison of laboratory data of the RLS and control groups

\begin{tabular}{|c|c|c|c|}
\hline & $\begin{array}{l}\text { RLS group } \\
(n=55)\end{array}$ & $\begin{array}{c}\text { Control group } \\
(n=35)\end{array}$ & $\mathbf{p}$ \\
\hline & Mean $\pm S D$ & Mean $\pm S D$ & \\
\hline FBG & $94.69 \pm 10.44$ & $90.82 \pm 8.89$ & 0.074 \\
\hline Urea & $27.45 \pm 7.42$ & $28.7 I \pm 8.57$ & 0.462 \\
\hline Creatinine & $0.75 \pm 0.16$ & $0.68 \pm 0.21$ & 0.078 \\
\hline Uric acid & $4.08 \pm 0.88$ & $4.30 \pm 1.27$ & 0.099 \\
\hline $\mathrm{TC}$ & $|95.5| \pm 45.74$ & $202.17 \pm 47.80$ & 0.850 \\
\hline TG & III. $62 \pm 58.63$ & $|02.1 I \pm 43.6|$ & 0.413 \\
\hline HDL-C & $53.92 \pm 10.07$ & $56.34 \pm 9.46$ & 0.261 \\
\hline LDL-C & $|I 7| I \pm 40.25$. & $125.20 \pm 40.23$ & 0.357 \\
\hline $\mathrm{HbAlc}$ & $5.63 \pm 0.34$ & $5.49 \pm 0.33$ & 0.061 \\
\hline $\mathrm{Fe}+2$ & $76.94 \pm 36.72$ & $85.14 \pm 42.49$ & 0.334 \\
\hline Ferritin & $28.24 \pm 31.13$ & $27.64 \pm 16.59$ & 0.917 \\
\hline T3 & $3.18 \pm 0.41$ & $3.23 \pm 0.46$ & 0.552 \\
\hline $\mathrm{T} 4$ & $0.86 \pm 0.24$ & $0.84 \pm 0.14$ & 0.729 \\
\hline TSH & $1.75 \pm 0.86$ & $1.68 \pm 0.63$ & 0.670 \\
\hline Vitamin BI2 & $252.91 \pm 96.42$ & $286.48 \pm 106.14$ & 0.125 \\
\hline Folate & $7.76 \pm 3.69$ & $8.21 \pm 3.68$ & 0.578 \\
\hline CRP & $2.01 \pm 2.12$ & $2.47 \pm 2.62$ & 0.356 \\
\hline Sedimentation & $14.89 \pm 8.14$ & $16.20 \pm 8.67$ & 0.471 \\
\hline WBC & $7.04 \pm 1.85$ & $6.7 I \pm 1.83$ & 0.417 \\
\hline RBC & $4.5 I \pm 0.36$ & $4.60 \pm 0.35$ & 0.252 \\
\hline HGB & $13.13 \pm 1.38$ & $|3.4| \pm 1.67$ & 0.393 \\
\hline PLT & $229.52 \pm 55.36$ & $2 \mid 4.25 \pm 51.24$ & 0.193 \\
\hline
\end{tabular}

CRP: C-reactive protein; FBG: Fasting blood glucose; Fe+2: Iron; HbAlc: Glycated hemoglobin; HDL-C: High-density lipoprotein cholesterol; HGB: Hemoglobin; LDL-C: Low-density lipoprotein cholesterol; PLT: Platelet; RBC: Red blood cell; T3: Triiodothyronine; T4: Thyroxine; TC: Total cholesterol; TG: Triglyceride; TSH: Thyroid-stimulating hormone; WBC: White blood cell; SD: Standard deviation.

analysis. There was a negative correlation between the PCS and the IRLSSG scale, FSS, ESS, PSQI, BDI, and BAI 
(Table 4). Multivariate linear regression analysis determined that the influential variables on the PCS score were the FSS (B:-2.744, SE:0.789, Beta:-0.477, t:-3.49I; $p=0.00 \mathrm{I})$ and BDI (B:-0.378, SE:0.158, Beta:-0.355, t:2.398; $p=0.021$ ).

Table 4. Comparison of sleep, anxiety, depression, and quality of life scale scores in the RLS and control groups

\begin{tabular}{lcccc}
\hline & $\begin{array}{c}\text { RLS group } \\
(\mathbf{n}=55)\end{array}$ & & $\begin{array}{c}\text { Control group } \\
(\mathbf{n}=\mathbf{3 5})\end{array}$ & p \\
\cline { 2 - 3 } \cline { 5 - 5 } & Mean \pm SD & & Mean \pm SD & \\
\hline PSQI & $10.65 \pm 4.14$ & & $2.74 \pm 1.24$ & 0.001 \\
ESS & $6.33 \pm 4.19$ & & $2.46 \pm 2.05$ & 0.001 \\
ISS & $14.55 \pm 6.31$ & & $4.34 \pm 2.66$ & 0.001 \\
BDI & $16.56 \pm 9.01$ & & $5.89 \pm 3.89$ & 0.001 \\
BAI & $14.89 \pm 8.71$ & & $7.14 \pm 4.07$ & 0.001 \\
FSS & $3.46 \pm 1.67$ & & $1.12 \pm 0.76$ & 0.001 \\
PF & $65.73 \pm 20.73$ & & $74.71 \pm 19.71$ & 0.044 \\
RP & $38.51 \pm 34.85$ & $58.29 \pm 32.24$ & 0.008 \\
BP & $56.73 \pm 21.27$ & $70.46 \pm 18.98$ & 0.070 \\
GH & $61.25 \pm 19.17$ & $68.71 \pm 17.53$ & 0.066 \\
VT & $45.09 \pm 20.03$ & $56.29 \pm 22.73$ & 0.016 \\
SF & $61.39 \pm 24.94$ & $77.14 \pm 28.03$ & 0.007 \\
RE & $50.27 \pm 39.51$ & $66.65 \pm 38.81$ & 0.047 \\
MH & $63.58 \pm 17.08$ & $72.69 \pm 17.61$ & 0.017 \\
PCS & $44.01 \pm 9.61$ & $51.97 \pm 7.43$ & 0.001 \\
MCS & $42.23 \pm 11.33$ & $46.71 \pm 12.03$ & 0.083 \\
\hline & & &
\end{tabular}

BAI: Beck Anxiety Index; BDI: Beck Depression Index; BP: Bodily pain; ESS: Epworth Sleepiness Scale; FSS: Fatigue Severity Scale; GH: General health; ISI: Insomnia Severity Index; MCS: Mental Component Summary; MH: Mental health; PF: Physical functioning; PCS: Physical Component Summary; PSQI: Pittsburgh Sleep Quality Index; RE: Role - Emotion; RLS: Restless legs syndrome; RP: Role-Physical; SF: Social functioning; VT: Vitality; SD: Standard deviation.

Table 5. Pearson correlation analysis of PCS and studied variables

\begin{tabular}{lcc}
\hline & $\mathbf{r}$ & $\mathbf{p}$ \\
\hline Age & 0.003 & 0.979 \\
Body mass index & -0.176 & 0.097 \\
Duration of education & 0.142 & 0.181 \\
Onset of restless legs syndrome & 0.030 & 0.839 \\
Duration of restless legs syndrome & 0.066 & 0.630 \\
IRLSSG rating scale & -0.411 & $0.002^{*}$ \\
Insomnia Severity Index & -0.525 & $0.00 I^{*}$ \\
Fatigue Severity Scale & -0.630 & $0.001^{*}$ \\
Epworth Sleepiness Scale & -0.364 & $0.00 I^{*}$ \\
Pittsburgh Sleep Quality Index & -0.424 & $0.00 I^{*}$ \\
Beck Anxiety Index & -0.372 & $0.00 I^{*}$ \\
Beck Depression Index & -0.598 & $0.00 I^{*}$ \\
\hline Statistically significant at p<0.05. IRLSSG: International Restless Legs Syndro- \\
me Study Group; PCS: Physical Component Summary. &
\end{tabular}

\section{DISCUSSION}

In this study, we found a decrease in the quality of life determined by the SF-36, and the BDI and BAI revealed an increased frequency of the psychiatric symptoms of anxiety and depression. In addition, significantly higher levels of fatigue and depressive symptoms were found to be the most important determinants of poorer PCS scores in RLS patients.

Examinations of the relationship between RLS and SF-36 results in different societies have revealed differences. In their study of 985 members of the Japanese population, Kubo et al. ${ }^{[20]}$ found significant decreases in all physical components as well as those related to vitality, social functioning, and emotional functioning in RLS patients. In a study of 3433 patients in the US, lower scores in all areas of the SF-36 were detected in individuals with RLS, but the decline in physical domains was particularly emphasized. ${ }^{[2]}$ Kushida et al. ${ }^{[22]}$ suggested that RLS had a greater effect on the physical components of the SF-36 than its mental components. In this study, the PF, RP, VT, SF, and MH subcomponents of the SF-36 and the PCS score were significantly lower in idiopathic RLS patients when compared with healthy individuals.

It has been established that general and abdominal adiposity is typically greater in individuals with RLS, and that this relationship is meaningful, particularly among female patients. ${ }^{[23,24]}$ Patients with RLS generally have a higher BMI than those who do not. It has been reported that BMI may be a risk factor for nocturnal eating behavior, which is a specific component of clinical spectrum of RLS. ${ }^{[25]}$ The prevalence of psychiatric conditions such as depression, anxiety, and eating disorders is higher in obese patients compared with the general population. ${ }^{[2,26]}$

In an evaluation of sleep disorders in individuals with obesity, the PSQI, ISI, and ESS scores were statistically significantly higher. ${ }^{[28]}$ A cohort study involving 983 adults revealed that sleep duration of fewer than 5 hours was associated with a 2.8-times greater likelihood of obesity and increased with each $1.6 \mathrm{~kg} / \mathrm{m}^{2}$ in BMI. ${ }^{[2]]}$

Abnormalities in the hypothalamic-pituitary-adrenal axis and cortisol levels have been associated with the development of emotional disorders, obesity, and metabolic syndrome in patients with RLS. ${ }^{[30,31]}$ In this study, the BMI was significantly higher in idiopathic RLS patients, consistent with the association described in the literature. In addition, there was a positive relationship between BMI and the sleep quality and anxiety scores.

In a study of 85 RLS patients performed in the UK using the SF-36, Abetz et al. ${ }^{[32]}$ reported that RLS appeared to have a significant effect on quality of life. In another study, there was a significant correlation between the severity of RLS and all physical and mental health scale scores. [33] In this study, as in much of the literature, there was a negative correlation between PCS scores and RLS severity, but there was no correlation between RLS onset and 


\section{SF-36 components.}

Several factors that could have an impact on the quality of life of RLS patients have been investigated. Among those with RLS, depression and anxiety have been reported to be more common than in healthy individuals. ${ }^{[9,10]}$ Depression has been observed 2 to 4 times more frequently in RLS. [34-36] Dopaminergic dysfunction may be the most important factor affecting the pathophysiology of both depression and RLS. ${ }^{[37,38]} A$ significant reduction in D2 receptors in putamen nuclei in patients with RLS has been shown to be associated with symptom severity. ${ }^{[39]}$ The contribution of chronic sleep deprivation contributes to depression, especially in patients with severe RLS with daytime symptoms. ${ }^{[40,41]}$ Svetel et al. ${ }^{[42]}$ indicated that symptoms of depression and anxiety were among the greatest potential determinative factors for deterioration in all of the SF-36 components. In our study, anxiety and depression symptoms were significantly higher in RLS patients with daytime sleepiness, and depression symptoms were among the influential variables for the PCS score.

More than half of patients with chronic fatigue have a diagnosis of a sleep disorder, such as RLS, obstructive sleep apnea, or periodic limb movement disorder. ${ }^{[43]}$ Fatigue and daytime sleepiness have been analyzed in RLS patients and were determined to have an effect on the quality of life ${ }^{[8]}$ Our research also found that fatigue was among the factors that may contribute to a worse PCS score.

The most important limitation of this study is that additional assessment tools beyond the PSQI, such as polysomnography, could not be applied. A careful evaluation was used to try to eliminate other possible sleep disorders. Furthermore, the study did not examine the effect of treatment on quality of life or depression and anxiety in RLS patients.

\section{CONCLUSION}

The results of this study indicated that idiopathic RLS was associated with a poorer quality of life and with the presence of the psychiatric symptoms of anxiety and depression. Further studies are needed to determine possible neurophysiological mechanisms and to evaluate the effects of treatment.

Ethics Committee Approval

Approved by the local ethics committee.

Peer-review

Internally peer-reviewed.

Authorship Contributions

Concept: Ş.A., C,Ö.; Design: Ş.A., C,Ö.; Supervision: Ş.A., C,Ö.; Data: Ş.A.; Analysis: Ş.A.; Literature search: Ş.A.; Writing: Ş.A.; Critical revision: Ş.A., C,Ö.

Conflict of Interest

None declared.

\section{REFERENCES}

1. Allen RP, Picchietti DL, Garcia-Borreguero D, Ondo WG, Walters AS, Winkelman JW, et al.; International Restless Legs Syndrome Study Group. Restless legs syndrome/Willis-Ekbom disease diagnostic criteria: updated International Restless Legs Syndrome Study Group (IRLSSG) consensus criteria-history, rationale, description, and significance. Sleep Med 2014;15:860-73. [CrossRef]

2. Ekbom K, Ulfberg J. Restless legs syndrome. J Intern Med 2009;266:419-31. [CrossRef]

3. Sevim S, Dogu O, Camdeviren H, Bugdayci R, Sasmaz T, Kaleagasi $\mathrm{H}$, et al. Unexpectedly low prevalence and unusual characteristics of RLS in Mersin, Turkey. Neurology 2003;61:1562-9. [CrossRef]

4. Özbek SE, Zarifoğlu M, Karlı N, Özçakır A, Yıldız D, Aslan D. A Population-Based Survey to Determine the Prevalence of Movement Disorders in Orhangazi District of Bursa, Turkey. Turk Norol Derg 2009;15:109-18.

5. Yilmaz NH, Akbostanci MC, Oto A, Aykac O. Prevalence of restless legs syndrome in Ankara, Turkey: an analysis of diagnostic criteria and awareness. Acta Neurol Belg 2013;113:247-51. [CrossRef]

6. Berger K, Kurth T. RLS epidemiology--frequencies, risk factors and methods in population studies. Mov Disord 2007;22 Suppl 18:S420-3. [CrossRef]

7. Durgin T, Witt EA, Fishman J. The Humanistic and Economic Burden of Restless Legs Syndrome. PLoS One 2015;10:e0140632.

8. Gerhard R, Bosse A, Uzun D, Orth M, Kotterba S. Quality of life in restless legs syndrome. Influence of daytime sleepiness and fatigue. [Article in German] Med Klin (Munich) 2005;100:704-9. [CrossRef]

9. Sevim S, Dogu O, Kaleagasi H, Aral M, Metin O, Camdeviren H. Correlation of anxiety and depression symptoms in patients with restless legs syndrome: a population based survey. J Neurol Neurosurg Psychiatry 2004;75:226-30.

10. Cho CH, Kim L, Lee HJ. Individuals with Restless Legs Syndrome Tend to have Severe DepressiveSymptoms: Findings from a Community-Based Cohort Study. Psychiatry Investig 2017;14:887-93. [CrossRef]

11. Walters AS, LeBrocq C, Dhar A, Hening W, Rosen R, Allen RP, et al.; International Restless Legs Syndrome Study Group. Validation of the International Restless Legs Syndrome Study Group rating scale for restless legs syndrome. Sleep Med 2003;4:121-32. [CrossRef]

12. Ağargün MY, Kara $H$, Anlar $\mathrm{O}$. The Validity and Reliability of the Pittsburgh Sleep Quality Index. Turkish Journal of Psychiatry 1996;7:107-15.

13. Ağargün MY, Çilli AS, Kara H, Bilici M, Telcioğlu M, Semiz ÜB, et al. The validity and reliability of the Epworth Sleepiness Scale. Turkish Journal of Psychiatry 1999;10:261-7.

14. Johns MW. A new method for measuring daytime sleepiness: the Epworth sleepiness scale. Sleep 1991;14:540-5. [CrossRef]

15. Boysan M, Güleç M, Beşiroğlu L, Kalafat T. Psychometric properties of the Insomnia Severity Index in Turkish sample. Anatolian Journal of Psychiatry 2010;11:248-52.

16. Hisli N. Beck Depresyon Envanterinin üniversite öğrencileri için geçerliliği, güvenirliği. Psikoloji Dergisi 1989;7:3-13.

17. Ulusoy M, Şahin N, Erkmen H. Turkish version of The Beck Anxiety Inventory: Psychometric properties. J Cogn Psychother 1998;12:2835.

18. Armutlu K, Korkmaz NC, Keser I, Sumbuloglu V, Akbiyik DI, Guney $Z$, et al. The validity and reliability of the Fatigue Severity Scale in Turkish multiple sclerosis patients. Int J Rehabil Res 2007;30:81-5. [CrossRef]

19. Demiral Y, Ergor G, Unal B, Semin S, Akvardar Y, Kivircik B, et al. Normative data and discriminative properties of short form 36 (SF36) in Turkishurban population. BMC Public Health 2006;6:247. 
20. Kubo K, Sugawara N, Kaneda A, Takahashi I, Nakamura K, Nakaji $\mathrm{S}$, et al. Relationship between quality of life and restless legs syndrome among a community-dwelling population in Japan. Neuropsychiatr Dis Treat 2016;12:809-15. [CrossRef]

21. Winkelman JW, Redline S, Baldwin CM, Resnick HE, Newman AB, Gottlieb DJ. Polysomnographic and health-related quality of life correlates of restless legs syndrome in the Sleep Heart Health Study. Sleep 2009;32:772-8. [CrossRef]

22. Kushida C, Martin M, Nikam P, Blaisdell B, Wallenstein G, FeriniStrambi L, et al. Burden of restless legs syndrome on health-related quality of life. Qual Life Res 2007;16:617-24. [CrossRef]

23. Kim J, Choi C, Shin K, Yi H, Park M, Cho N, et al. Prevalence of restless legs syndrome and associated factors in the Korean adult population: the Korean Health and Genome Study. Psychiatry Clin Neurosci 2005;59:350-3. [CrossRef]

24. Gao X, Schwarzschild MA, Wang H, Ascherio A. Obesity and restless legs syndrome in men and women. Neurology 2009;72:1255-61.

25. Antelmi E, Vinai P, Pizza F, Marcatelli M, Speciale M, Provini F. Nocturnal eating is part of the clinical spectrum of restless legs syndrome and an underestimated risk factor for increased body mass index. Sleep Med 2014;15:168-72. [CrossRef]

26. Hsu LK, Benotti PN, Dwyer J, Roberts SB, Saltzman E, Shikora $\mathrm{S}$, et al. Nonsurgical factors that influence the outcome of bariatric surgery: a review. Psychosom Med 1998;60:338-46. [CrossRef]

27. Lee ES, Kim YH, Beck SH, Lee S, Oh SW. Depressive mood and abdominal fat distribution in overweight premenopausal women. Obes Res 2005;13:320-5. [CrossRef]

28. Yildiz D, Buyukkoyuncu N, Kilic AK, Cander S, Yildız A, Gunes A, et al. Obesity: a possible risk factor for restless legs syndrome. Neurol Res 2017;39:1044-8. [CrossRef]

29. van den Berg JF, Knvistingh Neven A, Tulen JH, Hofman A, Witteman JC, Miedema HM, et al. Actigraphic sleep duration and fragmentation are related to obesity in the elderly: the Rotterdam Study. Int J Obes (Lond) 2008;32:1083-90. [CrossRef]

30. Schilling C, Schredl M, Strobl P, Deuschle M. Restless legs syndrome: evidence for nocturnal hypothalamic-pituitary-adrenal system activation. Mov Disord 2010;25:1047-52. [CrossRef]

31. Chrousos GP, Kino T, Charmandari E. Evaluation of the hypotha- lamic-pituitary-adrenal axis function in childhood and adolescence. Neuroimmunomodulation 2009;16:272-83. [CrossRef]

32. Abetz L, Allen R, Follet A, Washburn T, Earley C, Kirsch J, et al. Evaluating the quality of life of patients with restless legs syndrome. Clin Ther 2004;26:925-35. [CrossRef]

33. Allen RP, Stillman P, Myers AJ. Physician-diagnosed restless legs syndrome in a large sample of primary medical care patients in western Europe: Prevalence and characteristics. Sleep Med 2010;11:31-7.

34. Lee HB, Hening WA, Allen RP, Kalaydjian AE, Earley CJ, Eaton WW, et al. Restless legs syndrome is associated with DSM-IV major depressive disorder and panic disorder in the community. J Neuropsychiatry Clin Neurosci 2008;20:101-5. [CrossRef]

35. Li Y, Mirzaei F, O’Reilly EJ, Winkelman J, Malhotra A, Okereke OI, et al. Prospective study of restless legs syndrome and risk of depression in women. Am J Epidemiol 2012;176:279-88. [CrossRef]

36. Hornyak M. Depressive disorders in restless legs syndrome: epidemiology, pathophysiology and management. CNS Drugs 2010;24:89-98.

37. Finan PH, Smith MT. The comorbidity of insomnia, chronic pain, and depression: dopamine as a putative mechanism. Sleep Med Rev 2013;17:173-83. [CrossRef]

38. Clemens S, Rye D, Hochman S. Restless legs syndrome: revisiting the dopamine hypothesis from the spinal cord perspective. Neurology 2006;67:125-30. [CrossRef]

39. Allen R. Dopamine and iron in the pathophysiology of restless legs syndrome (RLS). Sleep Med 2004;5:385-91. [CrossRef]

40. Riemann D, Voderholzer U. Primary insomnia: a risk factor to develop depression? J Affect Disord 2003;76:255-9. [CrossRef]

41. Bastien $\mathrm{CH}$, Vallières A, Morin CM. Validation of the Insomnia Severity Index as an outcome measure for insomnia research. Sleep Med 2001;2:297-307. [CrossRef]

42. Svetel MV, Jovic JS, Pekmezovic TD, Kostic VS. Quality of life in patients with primary restless leg syndrome: community-based study. Neurol Sci 2015;36:1345-51. [CrossRef]

43. Pajediene E, Bileviciute-Ljungar I, Friberg D. Sleep patterns among patients with chronic fatigue: A polysomnography-based study. Clin Respir J 2018;12:1389-97. [CrossRef]

\section{Huzursuz Bacak Sendromu Ille Anksiyete, Depresyon ve Yaşam Kalitesi Arasındaki İlişki}

Amaç: Huzursuz bacaklar sendromu (HBS) sık karşısaşılan bir uyku bozukluğudur. HBS uyku bozukluğu dışında hayat kalitesini etkilemekte, yorgunluk ve psikiyatrik semptomlara neden olmaktadır. Bu çalışmada HBS'nin yaşam kalitesi ile anksiyete ve depresyon gibi psikiyatrik belirtiler üzerine etkisi araştırıldı.

Gereç ve Yöntem: Çalışmada nöroloji polikliniğinde HBS için sekonder nedenler dışlandıktan sonra idiyopatik HBS tanı kriterlerini karşılayan 55 hasta (7 erkek 48 kadın) ile herhangi bir hastalığı olmayan sağıılı 35 birey (8 erkek 27 kadın) değerlendirildi. Tüm bireylere Türkçe validasyonu yapılmış Pittsburg Uyku Kalite Ölçeği (PUKÖ), Epworth Uykululuk Ölçeği (EUÖ), Uykusuzluk Şiddet Ölçeği (UŞÖ), HBS şiddet skalası (IRLSSG), Beck Depresyon Ölçeği (BDÖ), Beck Anksiyete Ölçeği (BAÖ), Yorgunluk Şiddet Ölçeği (YŞÖ) ve yaşam kalitesi formu (SF-36) uygulandı.

Bulgular: İdiyopatik HBS tanı kriterlerini karşılayan 55 hasta Grup I, kontrol grubu olan sağıılı 35 birey Grup Il'de değerlendirildi. Tüm bireylere uygulanan PUKÖ, EUÖ, UŞÖ, BDÖ, BAÖ, YŞÖ, SF-36 anketlerinde HBS grubunda kontrol grubuna göre istatistiksel olarak anlamlı derecede fark gözlendi. HBS olgularında sağıılı bireylere göre özellikle SF-36 fiziksel bileşen özet ölçek (PCS) ortalama skoru anlamlı ölçüde düşük bulundu. PCS ile HBS şiddeti, yorgunluk, uykusuzluk, gün içi uykululuk, uyku kalitesi, anksiyete ve depressif belirtilerin seviyesi arasında negatif korelasyon mevcuttu. Çok değişkenli lineer regresyon analizi ile PCS skoru üzerinde etkili olası değişkenler olarak YşÖ ve BDÖ saptandı.

Sonuç: Bu çalışmada idiyopatik HBS'de yaşam kalitesi ile anksiyete ve depresyon gibi psikiyatrik belirtilerin önemli ölçüde bozulduğu gösterilmiştir.

Anahtar Sözcükler: Anksiyete; depresyon; huzursuz bacaklar sendromu; yaşam kalitesi. 